Corrigendum

\title{
Corrigendum to "A Versatile Orthotopic Nude Mouse Model for Study of Esophageal Squamous Cell Carcinoma"
}

\author{
Joseph Chok Yan Ip, ${ }^{1}$ Josephine Mun Yee Ko, ${ }^{1}$ Valen Zhuoyou Yu, ${ }^{1}$ Kwok Wah Chan, ${ }^{2,3}$ \\ Alfred K. Lam, ${ }^{4}$ Simon Law, ${ }^{3,5}$ Daniel King Hung Tong, ${ }^{5}$ and Maria Li Lung ${ }^{1,3}$ \\ ${ }^{1}$ Department of Clinical Oncology, University of Hong Kong, Hong Kong \\ ${ }^{2}$ Department of Pathology, University of Hong Kong, Hong Kong \\ ${ }^{3}$ Center for Cancer Research, University of Hong Kong, Hong Kong \\ ${ }^{4}$ Cancer Molecular Pathology, Griffith Medical School and Menzies Health Institute Queensland, Griffith University, \\ Gold Coast, QLD 4222, Australia \\ ${ }^{5}$ Department of Surgery, University of Hong Kong, Hong Kong \\ Correspondence should be addressed to Maria Li Lung; mlilung@hku.hk
}

Received 12 April 2016; Accepted 12 May 2016

Copyright (C) 2016 Joseph Chok Yan Ip et al. This is an open access article distributed under the Creative Commons Attribution License, which permits unrestricted use, distribution, and reproduction in any medium, provided the original work is properly cited.

In the article titled "A Versatile Orthotopic Nude Mouse Model for Study of Esophageal Squamous Cell Carcinoma” [1], the authors' affiliations were incorrectly listed. The correct affiliations are shown above.

\section{References}

[1] J. C. Y. Ip, J. M. Y. Ko, V. Z. Yu et al., "A versatile orthotopic nude mouse model for study of esophageal squamous cell carcinoma," BioMed Research International, vol. 2015, Article ID 910715, 10 pages, 2015. 


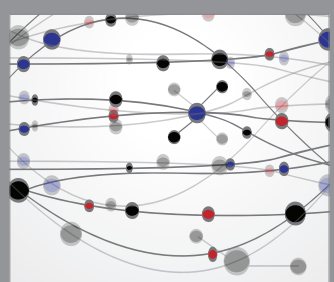

The Scientific World Journal
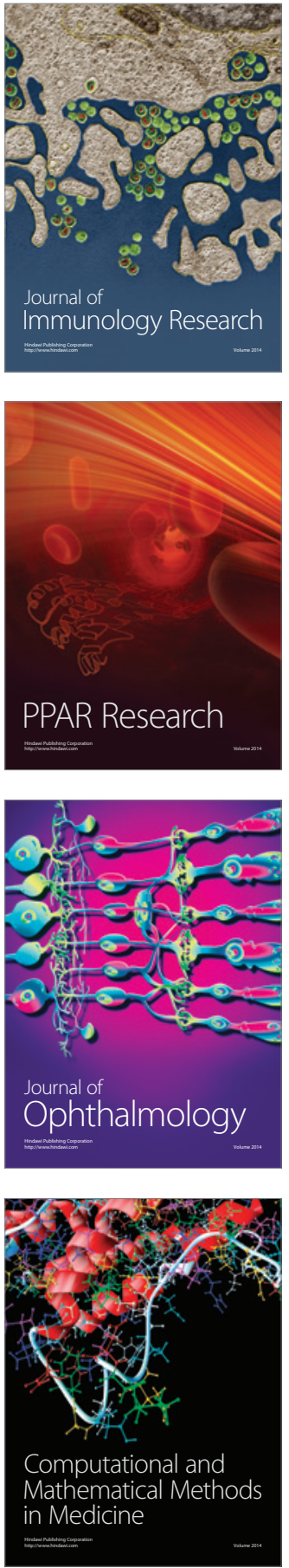

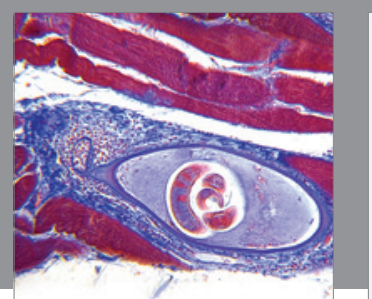

Gastroenterology Research and Practice

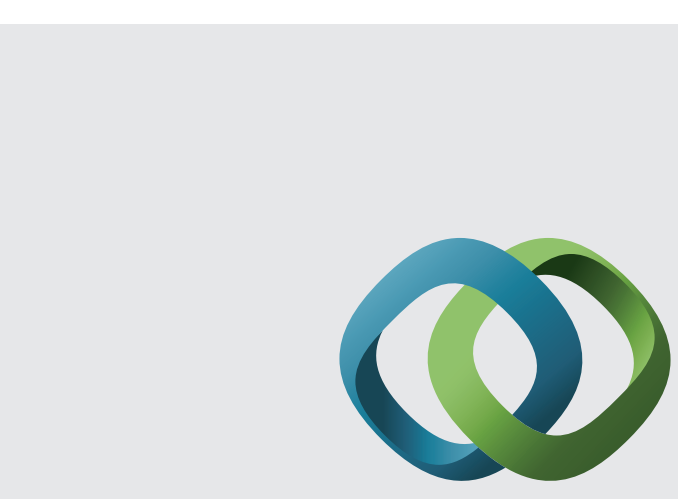

\section{Hindawi}

Submit your manuscripts at

http://www.hindawi.com
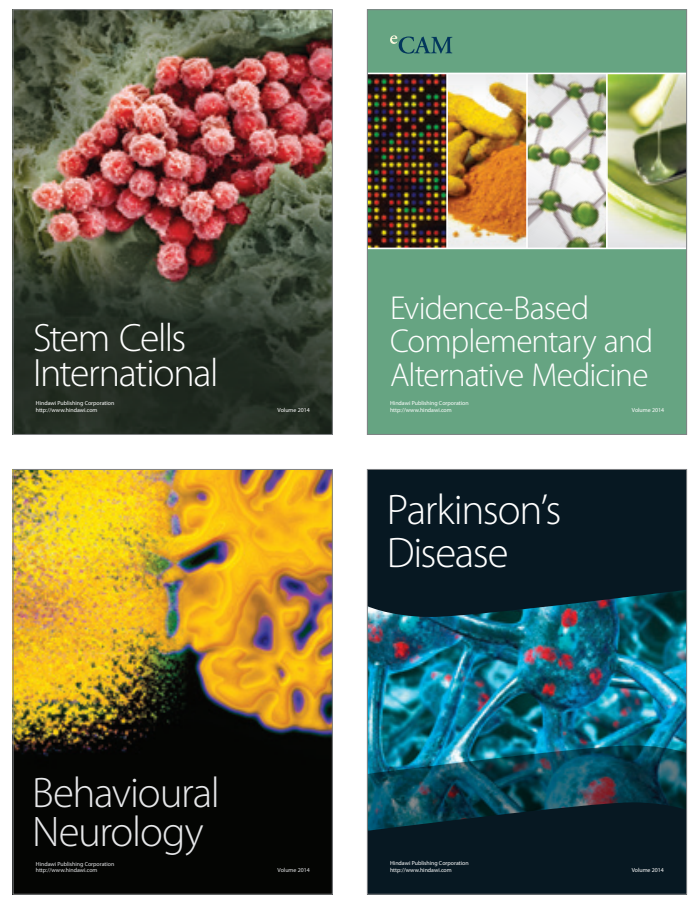
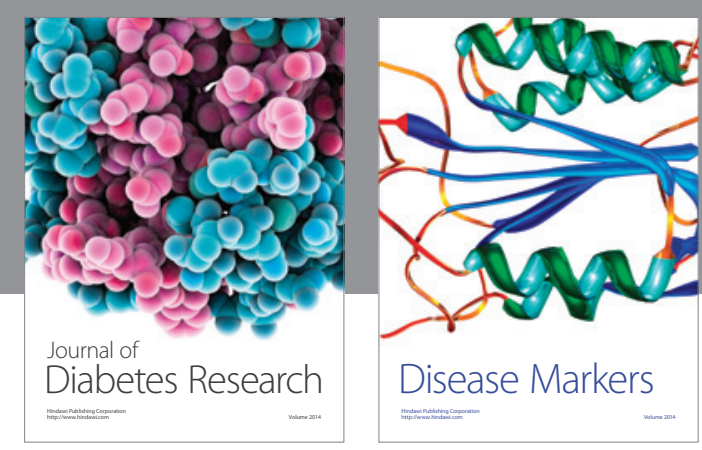

Disease Markers
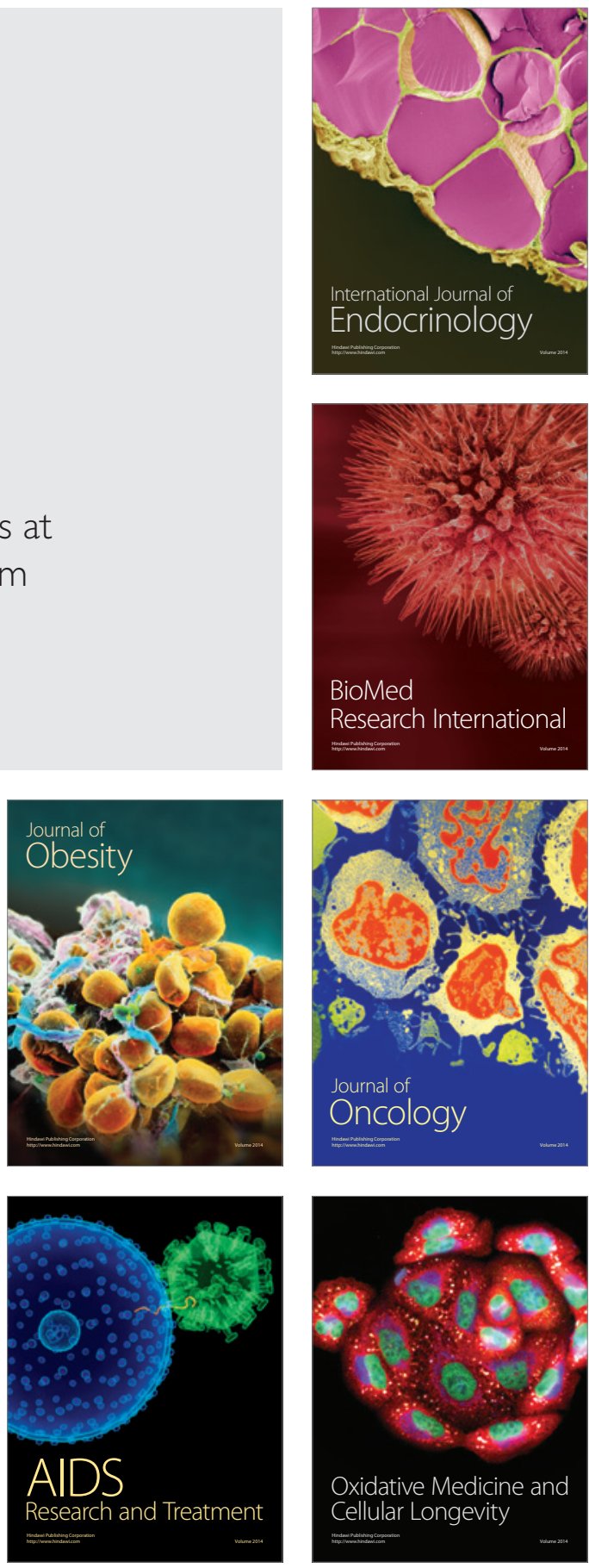